\title{
Autonomia wobec praw rządzących światem jako warunek życia prawdziwie moralnego $w$ filozofii Alberta Schweitzera
}

W swoich rozważaniach etycznych Albert Schweitzer jest skrajnie subiektywistyczny. Postuluje on autonomię wobec praw rządzących światem i postanawia określić naczelną zasadę moralną wyłącznie na podstawie wewnętrznego doświadczenia woli życia. Wynika to $z$ jego przeświadczenia o niemożności poznania sensu istnienia świata oraz $z$ obserwacji praw rządzących światem. Prawa te cechują się okrucieństwem i dopuszczają wzajemne niszczenie się istot żywych, na co człowiek moralny nigdy nie może się zgodzić. Dążenie do bycia wiernym wewnętrznej prawdzie swego bytu zmusza człowieka do pełnej afirmacji życia wbrew wszystkiemu, co dzieje się w otaczającym go świecie.

\section{Niemożność poznania sensu świata}

Dotychczasowe próby określenia sensu ludzkiego życia - zdaniem Schweitzera - oparte były na zasadniczym błędzie i dlatego pozostały bezowocne. Rzeczywistość interpretowano w duchu afirmacji świata $i$ życia, przyjmując, że świat ma określony cel i sens. Odkrycie tego sensu miało pozwolić na rozpoznanie sensu życia ludzkiego. Istnienie ludzkości, a następnie każde jednostkowe życie ludzkie miałoby zamierzać do tego samego celu, do którego zmierza wszechświat ${ }^{1}$. W myśleniu zachodnim dominuje więc przekonanie, jawnie artykułowane bądź ukryte, że świat ma sens oraz że jesteśmy w stanie ten sens rozpoznać. Myślenie to nastawione jest więc $w$ całości na uzasadnienie afirmacji świata ${ }^{2}$.

Diecezja Warszawsko-Praska.

1 Por. A. SCHWEITZER, Kultur und Ethik, w: Ausgewählte Werke in fünf Bänden, Berlin 1973, t. II, 102.

2 Por. H. BABEL, Die Ethik der Ehrfurcht vor dem Leben - eine Darstellung, w: Albert Schweitzer. Sein Denken und sein Weg, red. H. W. Bähr, Tübingen 1962, 26.

Dopóki pozostaje się w obszarze myślenia zachodniego, podejście takie wydaje się oczywiste. Jeżeli jednak przyjrzeć się na przykład myśli dalekowschodniej, można odkryć, że afir- 
Przekonanie, że świat ma sens, który można odkryć, Schweitzer określa jako optymistyczne i naiwne. Twierdzi on, że wszystkie próby stworzenia światopoglądu opartego na tym przekonaniu są powierzchowne i w rezultacie okazują się pozorne ${ }^{3}$. Bardzo sugestywnie ukazuje to w Kulturze i etyce w rozdziale Nowa droga: „W historii świata nie widać żadnej celowości, z którą mogłoby jakoś współgrać działanie ludzi i ludzkości. Na jednej $z$ mniejszych wśród milionów gwiazd żyją od niedawna istoty ludzkie. Jak długo jeszcze? Jakiś spadek czy wzrost temperatury Ziemi, przesunięcie osi gwiazdy, podniesienie poziomu morza czy jakaś zmiana w składzie atmosfery może położyć kres ich egzystencji, lub też Ziemia sama padnie ofiara jakiejś kosmicznej katastrofy, jak niektóre gwiazdy. Nie wiemy, jakie jest nasze znaczenie dla Ziemi. O ileż mniej jeszcze możemy rościć sobie prawo do nakładania na nieskończone uniwersum sensu, mającego nas na uwadze lub dającego się wyjaśnić poprzez naszą egzystencję!"4 . Jak długo próbuje się intelektualnie rozpoznawać ów ogólny sens świata, tak długo jest się skazanym na bezowocne trwanie w tym samym punkcie. Analiza tego, jaki jest świat, prowadzi do przerażających wniosków: światem nie rządzi duch życzliwości, raczej jesteśmy świadkami ciagłego zmagania się i walki różnych istot żyjacych. Aby przeżyć, należy nieustannie pozbawiać życia innych. „Świat jest tym, co okrutne $w$ tym, co wspaniałe, jest bezsensem $w$ tym, co peł-

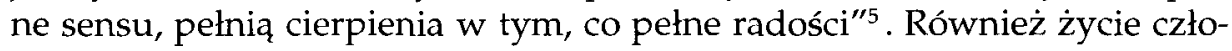
wieka jest nieustannie zagrożone. W każdej chwili może być ono tragicznie zakończone przez nieszczęśliwy wypadek, na który człowiek nie będzie miał żadnego wpływu. Ukazuje to, jak bardzo poddani jesteśmy bezsensownemu chaosowi ${ }^{6}$.

macja świata nie jest bynajmniej czymś oczywistym. Hinduizm na przyklad wprost neguje wartość świata i życia. Por. A. SCHWEITZER, Kultur und Ethik, dz. cyt., 104.

Wedle myślenia hinduistycznego, świat nie ma sensu, jest pozorny, jest grą urządzoną przez Boga. Angażowanie się w ten świat, afirmowanie go nie prowadzi do niczego, stąd ideałem staje się całkowite wycofanie się, nie-działanie. Schweitzer zauważa, że w różnych kierunkach myśli dalekowschodniej negacja świata prowadzić będzie do różnych wskazań odnośnie do angażowania się w świat. Bramińska idea nie-działania nie wszędzie znajduje poparcie. Bhagawadgita na przyklad zaleca, aby człowiek wziąl udział w prowadzonej przez Boga grze, którą są losy świata. Samo w sobie nie ma to sensu, należy jednak podjąć to zadanie w imię oddania się Bogu. Por. A. SCHWEITZER, Wielcy myśliciele Indii, tłum. z j. franc. K. i K. Pruscy, Warszawa 1993, 134.

3 Por. A. SCHWEITZER, Życie, tłum. z j. niem. J. Piechowski, Warszawa 1971, 31.

4 A. SCHWEITZER, Kultur und Ethik, dz. cyt., 335. Teks polski według: I. LAZARI-PAWEOWSKA, Schweitzer, Warszawa 1976, 179.

5 A. SCHWEITZER, Das Problem der Ethik in der Höherentwicklung des menschlichen Denkens, w: Ausgewählte Werke, dz. cyt., t. V, 157

6 Por. A. SCHWEITZER, Strassburger Vorlesungen, Werke aus dem Nachlaß, München 1998, 699. 


\section{Rezygnacja poznawcza}

Stwierdzając bezcelowość poszukiwania sensu świata, autor Kultury $i$ etyki proponuje zupełnie inne rozwiązanie: „rezygnację z optymistycznej - za wszelką cenę - i etycznej interpretacji świata"7. Skoro nie sposób przypisać światu sensu, rozpoznać znaczenie ewolucji, a tym bardziej odczytać na tej podstawie sens ludzkiego życia, aby pójść naprzód, potrzeba odważnego kroku rezygnacji z pragnienia poznania sensu świata. Akt ten jest aktem wierności prawdzie i nie musi prowadzić do sceptycy$\mathrm{zmu}^{8}$. Optymistyczne myślenie etyczne o życiu nie musi opierać się na optymistycznym myśleniu o świecie. Koncepcja życia nie jest zależna od światopoglądu ${ }^{9}$.

Schweitzer dokonuje tu rozróżnienia, które - jego zdaniem - jest zwrotnym punktem myślenia. To, co dotychczas nazywano światopoglądem, obejmuje pogląd na świat (Weltanschauung) i pogląd na życie (Lebensanschauung $)^{10}$. Zdaniem Schweitzera oba te poglądy nie stanowią jedności i nie można uzależniać poglądu na życie od rozumienia świata. Proponuje on uznać wzajemną autonomię owych dwóch ujęć i nie obawiać się ich konfrontacji. Stwierdza następnie, że w myśleniu o życiu dociera się dalej, niż wynikałoby to $\mathrm{z}$ poznania świata, i dochodzi się do przekonań, których nie da się udowodnić opierając się na samym poglądzie na świat ${ }^{11}$.

Akt poznawczej rezygnacji jest więc konieczny w celu sformułowania prawidłowo uzasadnionego światopoglądu. Każdy światopogląd, który nie zaczyna się od tej rezygnacji, jest zmyślony - przyjmuje wizję świata opartą na jakiejś jego interpretacji, która zostaje uznana za odczytanie rzeczywistego jego sensu. Tymczasem jest to jedynie interpretacja, przyjęta w sposób arbitralny, albowiem faktycznego sensu istnienia świata nie da się dociec ${ }^{12}$.

7 A. SCHWEITZER, Kultur und Ethik, dz. cyt., 104.

Por. tamże, 105.

Por. H. CLARK, The Philosophy of Albert Schweitzer, London 1964, 33.

10 Termin Weltanschauung - który potocznie tłumaczy się przez „światopogląd” - oznacza, według Schweitzera, przekonania dotyczące istoty i celu świata oraz miejsca czlowieka w świecie. Gdy mówi o dążeniu do określenia całościowej wizji świata używa terminu Toralweltanschauung (Por. A. SCHWEITZER, Verfall und Wiederaufbau der Kultur, w: Ausgewählte Werke in fünf Bänden, Berlin 1973, t. II, 25 i 30n.), co można przetłumaczyć jako 'całościowy pogląd na świat'. Trudno jest w prosty sposób przełożyć na język polski termin Lebensanschauung (dosł. życiopoglqd), słowo oznaczające subiektywne przekonanie czlowieka, jakie znaczenie ma dla niego jego życie i jakie cele chce mu nadać. W szerszym sensie oznacza ono rozumienie znaczenia życia ludzkiego w ogólności. Tak wyjaśnia to pojęcie Lee Ellerbrock w niepublikowanym eseju cytowanym przez H. Clarka w The Philosophy, dz.cyt., 28. Lazari-Pawłowska oddaje ten termin przez 'pogląd na życie' lub 'koncepcja życia', np. w dwóch miejscach na s. 164 zbioru Schweitzer, Warszawa 1976 (tekst oryginalny: A. SCHWEITZER, Kultur und Ethik, dz.cyt., 106).

11 Por. A. SCHWEITZER, Kultur und Ethik, dz.cyt., 339.

12 Por. tamże, 105. 
Schweitzer rezygnuje $z$ afirmacji świata i życia opartej na poznaniu. Nie oznacza to jednak rezygnacji $z$ myślenia. Nie mogąc dociec sensu wszechświata, umysł zwraca się ku temu, co Schweitzer nazywa „myśleniem elementarnym, prawdziwym myśleniem" ${ }^{\prime 13}$. W ramach takiego myślenia stawia się podstawowe pytania dotyczące ludzkiej egzystencji: o stosunek człowieka do świata, o sens ludzkiego życia, o istotę dobra moralnego. Człowiek stawiający sobie te pytania w sposób rzetelny i konsekwentny, musi dojść do jasnych rozstrzygnięć moralnych. Jeżeli ktoś twierdzi, że refleksja doprowadziła go do moralnego sceptycyzmu, nie mamy - zdaniem Schweitzera - do czynienia z prawdziwym myśleniem. $W$ odniesieniu do oceny racjonalizmu Schweitzer pozostaje optymistą: do wszelkich osiągnięć ducha dochodzi się drogą racjonalnego myślenia ${ }^{14}$. Najgłębsze prawdy etyczne narzucają się człowiekowi w sposób oczywisty. Gdy doprowadzi do końca myślenie o swoim życiu, prawdy te docierają z taką jasnością, że nie sposób się od nich uwolnićc ${ }^{15}$.

Rezygnacja z afirmacji świata i życia opartej na poznaniu sensu świata nie oznacza również odrzucenia tej afirmacji w ogóle, lecz poszukiwanie jej źródła gdzie indziej. Jeśli nie da się zbudować etyki na światopoglądzie, to pierwszym krokiem oświeconego umysłu powinna być rezygnacja z tęsknoty za pełną wiedzą o świecie. Potrzebna jest „uczona ignorancja" (docta ignorantia) człowieka świadomego granic, których jego poznanie nie jest $\mathrm{w}$ stanie przekroczyćc ${ }^{16}$.

Ukazany tu pesymizm poznawczy $\mathrm{w}$ odniesieniu do świata, to jest przekonanie, że nie da się odkryć jego sensu - nie prowadzi Schweitzera do negacji świata ${ }^{17}$. Człowiek mimo braku wiedzy na temat celu świata pozostaje $w$ nim i przez to afirmuje ten świat i swoją $w$ nim egzysten$\mathrm{cję}^{18}$. Nie znajdując racji dla afirmacji świata i życia w rozumieniu świata, należy szukać jej poza tym rozumieniem.

3 Por. H. Cl.ARK, The Philosophy, dz. cyt., 32.

14 Por. tamże, 38.

15 Por. A. SCHWEITZER, Das Problem, dz. cyt., 157.

16 Por. H. CLARK, The Philosophy, dz. cyt., 33.

17 Rezygnacja poznawcza Schweitzera nie ma nic wspólnego ze „zwątpieniem” egzystencjalistów. Nie mogąc rozpoznać sensu świata i swego życia, oddają się oni absurdowi i nie są w stanie nawiązać pozytywnej relacji ze światem, drugim czlowiekiem i wydarzeniami. Dla Schweitzera rezygnacja $z$ dociekania sensu świata oznacza możliwość swobodnego oddania się życiu, zwrócenia się do świata bez konieczności odczytania celu jego istnienia. Por. J. B. HYGEN, Niedergang und Wiederaufbau der Kultur-Die Kulturphilosophie Albert Schweitzers, w: Albert Schw'eitzer. Sein Denken und sein Weg,dz. cyt., 13n.

18 Por. M. ECKER. Evolution und Ethik. Der Begriff der Denknotw'endigkeit in Albert Schw'eitzers Ethik der Ehrfurcht vor dem Leben, w: Albert Schweitzer heute. Brennpunkte seines Denkens, red. C. Günzler, E. Grässer. B. Christ. H. H. Eggebrecht, Tübingen 1990, 58. 


\section{Wyższość doświadczenia wewnętrznego nad wiedzą płynącą z poznania świata}

Schweitzer ukazuje fundamentalne znaczenie, jakie dla myślenia ma relacja pomiędzy poznaniem i wolą. Te dwie władze ludzkiego umysłu są ściśle związane i muszą ze sobą współdziałać. Waga tego współdziałania w szczególny sposób ujawnia się, gdy podjęte zostaje myślenie dotyczące najgłębszej wiedzy człowieka, czyli wiedzy o życiu. Schweitzer uznaje życie za najbardziej podstawowy przedmiot wiedzy. Wiedzę o życiu określa mianem ostatecznego stanu wiedzy (letzter Gegenstand des Wissens). Życie postrzegane jest przez człowieka $w$ dwojaki sposób: od zewnątrz (przez poznanie) oraz od wewnątrz (przez wolę). Połączenie tych dwóch sposobów postrzegania prowadzi człowieka do rozumnego (dosł. myślącego) przeżywania życia. Przeżywanie to daje człowiekowi możliwość odnalezienia się w świecie i pojęcia siebie samego - do głębi ${ }^{19}$.

Dogłębne przeżywanie tajemnicy życia nie może być oddzielone od rozumu. Wola człowieka jedynie wtedy zdolna będzie ogarnąć tę tajemnicę, gdy pozostawać będzie we właściwym stosunku do poznania. Gdy człowiek nie uwzględnia rzetelnie efektów poznania, jego wolitywna próba zgłębienia tajemnicy życia przeradza się $w$ niejasne fantazjowanie. Jeśli jednak chciałby on - jak uczynili to racjonaliści - ograniczyć się do samego poznania rozumowego i zdystansuje się do opartego na rozumie przeżycia, nie będzie w stanie pojać tajemnicy życia i nie zdoła stworzyć głębokiego, w elementarny sposób uzasadnionego światopoglądu ${ }^{20}$.

$\mathrm{Na}$ gruncie tak rozumianego racjonalizmu Schweitzer tworzy swoje ujęcie etyki: „Etyka powstaje dzięki temu, że doprowadzam do końca myślenie o afirmacji świata, jaka w sposób naturalny dana jest wraz $\mathrm{z}$ afirmacją życia w mojej woli życia i że próbuję tę afirmację świata urzeczywistnić" ${ }^{21}$. Wedle jego przekonania, etyka ta jest „racjonalizmem domyślanym do końca"22. Racjonalizm ten ma jednak swój specyficzny charakter, albowiem oparty jest na poznawczej rezygnacji. „Rezygnując z pomocy idealizmu teoriopoznawczego, etyka nie oczekuje już niczego od spekulatywnej filozofii, wyrzeka się wszelkiej etycznej interpretacji świata"$^{\prime 23}$. Wszelkie idee, według których człowiek ksztaltuje swe życie dane są w jego woli życia. Każdy nosi je w sobie i nie musi tworzyć ich przez myślenie. $W$ procesie myślowym człowiek jedynie rozpoznaje te idee, formułuje je oraz zajmuje wobec nich stanowisko ${ }^{24}$.

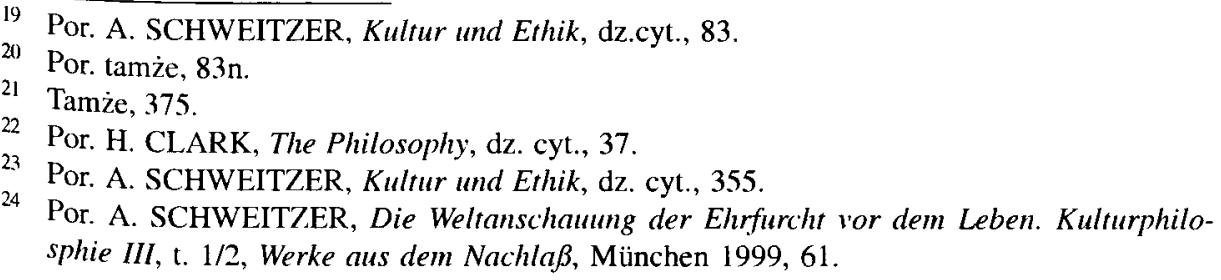


Wola życia, zdaniem Schweitzera, nie musi ograniczać się do niewystarczającego przecież poznania świata, może zwrócić się do tego, co znajduje w sobie. Nie warto nakazywać woli życia zniżać się do poznawania świata ani próbować podnosić na jej wyżyny bezsensownego przedsięwzięcia, za jakie Schweitzer uważa poznawanie świata, skoro „poznanie płynące z mojej woli życia jest bogatsze od tego, które zyskuję $\mathrm{z}$ obserwacji świata. Są w niej wartości i poruszenia postępowania wobec świata i życia, których nie da się usprawiedliwić na podstawie myślenia o świecie i bycie (...) Oczywistość i prawda polegają na tym, by idee, które dane są w woli życia uznać za wyższe i rozstrzygające. Moja wiedza o świecie jest wiedzą z zewnątrz i zawsze pozostaje niekompletna. Wiedza $z$ mojej woli życia jest jednak bezpośrednia i odnosi się do tajemniczych poruszeń życia takiego, jakie ono jest samo w sobie"25.

\section{Rozpoznanie woli życia w sobie $\mathrm{i}$ w innych}

W myśleniu elementarnym należy więc zwrócić się do wnętrza podmiotu. Jeśli człowiek to uczyni, odnajduje w sobie przemożną wolę życia. Najbardziej bezpośrednio stwierdzanym faktem świadomości jest: "Jestem życiem, które chce żyć, pośród życia, które chce żyć" (Ich bin Leben, das leben will, inmitten von Leben, das leben will ${ }^{26}$. Twierdzenie to nie jest według jego autora - wymyśloną tezą, lecz prawdą, która dociera do nas wciąż na nowo w każdej chwili zastanowienia.

Doświadczenie siebie jako woli życia ma charakter pierwotny i staje się punktem wyjścia do dalszej analizy rozumowej. Rezygnując z nieosiągalnego poznawania sensu świata, rozum poszukuje jasności na temat tkwiącej w człowieku woli życia oraz jej odniesienia do siebie samej i do świata. Rozpoznawszy swoją wolę życia, człowiek - przez analogię - odkrywa podobną wolę we wszystkim wokół siebie. Skutkiem podjęcia nieuwarunkowanego myślenia wywodzącego się z rozumu nad rozpoznanym w świecie fenomenem powszechnej woli życia jest osiągnięcie przekonania, że jedynym słusznym podejściem do życia swego i innych jest cześć wobec niego ${ }^{27}$. Etyka czci dla życia jest - zdaniem Schweitzera koniecznością myśli ludzkiejeje. Doprowadzone do końca myślenie o afirmacji świata i życia danych w naszej woli życia staje się myśleniem etycznym. Schweitzer utrzymuje, że "stać się etycznym oznacza stać się prawdziwie myślącym"29, a zarazem obserwuje zależność odwrotną. Stwier-

\footnotetext{
Por. A. SCHWEITZER, Kultur und Ethik, dz. cyt., 345.

Por. tamże, 377.

27 Por. tamże, 107n.

28 Por. H. CLARK, The Philosophy, dz. cyt., 35.

29 Por. A. SCHWEITZER, Kultur und Ethik, dz. cyt., 37.5 ,
} 
dza mianowicie, że „kto poważnie przebada głębię myśli, musi dotrzeć do tego punktu - być naprawdę racjonalnym oznacza stać się etycznym. Jakże zadowolony byłby Sokrates, słysząc nas mówiących to!"30

Powyższe ujęcie etyki ma więc charakter jednoznacznie podmiotowy, w którym subiektywne doświadczenie własnej woli życia staje się punktem wyjścia i ostatecznym odniesieniem dla dalszych analiz rozumowych. Podobnie ukazuje to Clark, stwierdzając, że uzyskane przez Schweitzera tezy są owocem odwrócenia się od świata, zwrócenia ku sobie i swemu wewnętrznemu doświadczeniu, oraz głębokiej medytacji rzeczywistości, która tam się znajduje ${ }^{31}$. Sam Schweitzer stwierdza, że początkiem wszelkiego myślenia jest myślenie o sobie samym ${ }^{32}$.

Podmiotowe ujęcie racjonalizmu doprowadza Schweitzera do zaskakujących konsekwencji. Niemożność poznania sensu świata nie przeszkadza w zgłębianiu poruszeń woli życia. Człowiek powinien podtrzymywać i pogłębiać afirmację życia i świata, albowiem jego życie posiada swój sens $w$ sobie. Leży on w służbie najwyższej idei - idei czci dla życia $^{33}$. Tak ujęty racjonalizm, doprowadzony do końca, przechodzi zdaniem Schweitzera - w irracjonalizm, gdyż afirmacja życia i świata, a wraz $z$ nią i etyka, nie mają uzasadnienia w żadnym adekwatnym poznaniu świata. Nie wiemy także, jakie znaczenie dla świata może mieć działanie motywowane usposobieniem czci dla życia. Wynika stąd, że jest ono irracjonalne i trzeba mieć odwagę uznania tego. "Jeśli racjonalne myślenie doprowadzimy do końca, dojdziemy w konieczny sposób do irracjonalności. Jest to paradoks, opanowujący nasze życie duchowe. Gdy próbujemy obyć się bez tej irracjonalności, powstaje pozbawiony wartości martwy pogląd na świat i życie" ${ }^{\prime 34}$. Schweitzer uważa, że każde wartościowe przekonanie jest irracjonalne i ma charakter entuzjastyczny, ponieważ nie pochodzi z poznania świata, lecz z opartego na myśleniu przeżywania woli życia i zdecydowanie owo poznanie przekracza. Taki jest ostateczny efekt domyślanego do końca myślenia rozumowego ${ }^{35}$.

\section{Etyka prawdziwości wobec siebie}

$\mathrm{Na}$ skutek zwrócenia się ku wnętrzu podmiotu, w etycznym myśleniu Schweitzera problem afirmacji własnego życia wysuwa się przed problem

\footnotetext{
30) Por. A. SCHWEITZER, The Ethics of Reverence for Life, w: Christendom I, Winter 1936, no. 2, przedruk w: H. CLARK, The Philosophy, dz. cyt., 186.

31 Por. H. CLARK, The Philosophy, dz. cyt., 33.

32 Por. A. SCHWEITZER. Die Weltanschauming der Ehrfurcht, dz. cyt., t. 1/2, 173.

33 Por. A. Schweitzer, Kultur und Ethik, dz. cyt., 107n.

34 Por. tamże, 110.

35 Por. tamże.
} 
afirmacji życia innych. Chcąc ukazać najgłębsze uzasadnienie etyki, Schweitzer wskazuje na dążenie do doskonałości. Definiuje on etykę jako "działalność człowieka skierowaną na wewnętrzną doskonałość jego osobowości"36. Ostatecznym motywem działania etycznego okazuje się dążenie do prawdziwości wobec siebie (Wahrhaftigkeit gegen sich selbst), która jest niezwykłym osiągnięciem człowieka. „Stawiam siebie pod przymus prawdziwości wobec siebie. Za drogo zostało okupione to wszystko, co osiągnalem przez działanie wbrew swemu przekonaniu. Obawiam się, abym przez niewierność sobie nie zranił mej woli życia zatrutym grotem"37.

Ostateczne kryterium etyczne ma więc charakter wewnętrzny, podmiotowy. Nie odnosi się ono do obiektywnej normy dobra, lecz do wewnętrznej prawdy ludzkiego ducha. Schweitzer ukazuje to, przedstawiając różne motywy, które można przypisać jakiemuś czynowi. Etyka prawdziwości wobec siebie w praktyce staje się etyką oddania się innym, stąd działania $\mathrm{z}$ niej wynikające jawią się jako akty oddania się. W związku z tym są one na ogół błędnie rozumiane jako wypływające z postawy oddania się. Prawdziwym jednak motywem jest wierność prawdzie swojego istnienia. Schweitzer obrazuje to na przykładzie aktu przebaczenia. W zwykłym myśleniu etycznym przyjmuje się, że człowiek wybacza drugiemu z powodu współczucia. W ten sposób zezwala się człowiekowi na przerażającą pewność siebie i przebaczanie, które nie jest wolne od upokorzenia tego, komu się wybacza. Przebaczenie staje się „przesłodzonym triumfem oddania $s^{\prime \prime} e^{\prime 38}$. W rzeczywistości każda wyrozumiałość i przebaczenie powinny być wynikiem nakazu prawdziwości wobec siebie. Człowiek jest zobowiązany do bezgranicznego przebaczania, albowiem nie przebaczając, byłby niewierny prawdzie swego „ja” (unwahrhaftig gegen sich selbst), postępując tak, jakby sam nie był winny. Ponieważ każdemu zdarza się kłamać, być nielitościwym, nienawistnym itd., dlatego należy wybaczać innym takie postępowanie $^{39}$. "Nie $z$ powodu dobroci dla innych jestem dla nich lagodny, zgodny, cierpliwy i przyjazny, ale dlatego, że przez takie postępowanie dokonuję najgłębszego potwierdzenia siebie"

36 A. SCHWEITZER, Verfall, dz. cyt., 85.

37 Por. A. SCHWEITZER, Kultur und Ethik, dz. cyt., 383n.

38 Por tamże, 384.

39 Por. tamże, 383-385. Schweitzer posuwa się jeszcze dalej. Stwierdza, że żyjąc w prawdzie człowiek w ogóle nie przebacza, bowiem nie dopuszcza, aby dochodziło do osądzania drugiego. Mówi, że walkę ze złem należy prowadzić nie przez sądzenie innych, lecz siebie. Zmaganie się ze sobą i prawdziwość wobec siebie są środkami, przez które oddziałuje się na innych. Por. tamże, 385.

4)

Por. tamże, 385. 


\section{Konieczność bycia innym niż świat}

W otaczającym nas świecie Schweitzer dostrzega wewnętrzne rozdwojenie (Selbstentzweiung) woli życia. W istotach nierozumnych wola ta występuje $\mathrm{w}$ postaci zindywidualizowanej, zmierzającej jedynie do zrealizowania siebie. Nie widać dążenia do jedności z innymi, żyje się kosztem innych. Aby utrzymać się przy życiu, wciąż należy uśmiercać inne istoty. Istoty nierozumne realizują swą wolę życia w sposób ślepy, nie interesując się losem innych, nie wiedząc nic o istnieniu $w$ nich woli życia. Jedynie człowiek, w którym wola życia stała się świadoma, zwraca się $\mathrm{ku}$ innym istotom żyjącym, starając się o jedność $\mathrm{z}$ nimi ${ }^{41}$.

W człowieku, który kieruje się normami etycznymi, wola życia znajduje się w wewnętrznym konflikcie. Obok naturalnego dążenia do utrzymania się przy życiu, które także człowiek realizuje kosztem innych istot żywych, pojawia się inne dążenie. Jest to staranie o doprowadzenie siebie samego, ale także każdego życia, na które ma się wpływ, do najwyższej wartości materialnej i duchowej. Nie wiadomo, skąd to dążenie bierze się $w$ człowieku, należy jednak być mu posłusznym, jeśli chce się być wiernym obecnej $w$ sobie woli życia ${ }^{42}$. Aby służyć dobru innej istoty $\mathbf{i}$ oddając się jej, chronić ją przed krzywdą lub zniszczeniem, człowiek dokonuje aktu negacji własnego życia ${ }^{43}$. W ten sposób dokonuje się proces wyższej afirmacji życia, domagającej się ograniczenia naturalnych impulsów życia, negacji swego życia w jego niższym wymiarze - w imię wyższego celu, jakim jest dobro innej istoty żywej" ${ }^{44}$. Negacja taka czyni człowieka wolnym wobec świata i wobec siebie samego. Pozwala mu to działać w świecie w prawidłowy sposób ${ }^{45}$.

Decydującą rolę $w$ procesie realizowania pełnej, wyższej afirmacji życia - odgrywa myślenie. Na drodze rozumowej człowiek przekonuje się, że jest zobowiązany do tego, by analogicznie do afirmacji własnego życia uznać i afirmować wolę życia, która objawia się w otaczających go bytach. Dostrzeżenie tej woli w istotach otaczajacych człowieka i decyzja, aby ją uszanować, staje się aktem afirmacji świata. Na gruncie tej afirmacji świata negacja życia staje się środkiem do afirmacji życia znajdującego się obok. „Etyka jest tajemniczym trójdźwiękiem, w którym afirmacja życia i afirmacja świata rozbrzmiewają jako ton podstawowy i kwintá. Negacja życia jest tercją"46. Negacja życia, choć konieczna w etyce, nie

41 Por. A. SCHWEITZER, Kultur und Ethik, dz. cyt., 381.

42 Por. tamże, 341-346.

4.7 Por. tamże, 355.

44 Por. H. CLARK, The Philosophy, dz. cyt., 25n.

45 Por. A. Schweitzer, Die Weltanschauung der Ehrfurcht, dz. cyt., t. 1/2, 174.

4h A. SCHWEITZER, Kultur und Ethik, dz. cyt., 356. 
może jednak być jej podstawą. Nawiązując do ukazanego powyżej muzycznego porównania Schweitzer stwierdza, że negacja życia nie może stanowić tonu podstawowego. Znajduje się ona na właściwym miejscu jedynie wówczas, gdy rozbrzmiewa wspólnie $\mathrm{z}$ afirmacją życia, która jest tonem podstawowym ${ }^{47}$.

Ponieważ - zdaniem Schweitzera - wola życia jest w świecie rozdwojona i nieustannie dokonuje się dzieło niszczenia życia, próba zbudowania etyki opartej na prawach rządzących światem prowadzi do zniechęcenia i pesymizmu. Etyka nie może być zgodna $\mathrm{z}$ tym, co dzieje się w świecie (Weltgeschehen) - powinna stanowić akt zdecydowanego sprzeciwu wobec tego. Schweitzer uważa, że człowiek etyczny musi być inny niż świat, że etyka powinna być aktem jego duchowego samostanowienia $^{48}$. Dzieje się tak, ponieważ człowiek moralny popada w nieuchronne napięcie $z$ naturą, która nie jest moralna, nie ma określonego celu i zdominowana jest przez prawo pożerania innych i bycia pożeranym ${ }^{49}$. Wola życia powinna zatem zostać ostatecznie uwolniona od pragnienia rozumienia świata i kierować się jedynie tym, co dane jest w niej samejo ${ }^{50}$.

Za najwyższą wiedzę uznaje Schweitzer przekonanie, że należy być wiernym woli życia. To wskazanie jest dla niego wystarczającym kryterium ludzkich działań. Docierając do jasnego zrozumienia swej woli życia człowiek odkrywa, że jest ona ukierunkowana na samą siebie, na zrealizowanie swej pełni. Zadaniem więc człowieka świadomego jest uzyskanie wolności od otaczającego go świata i zrealizowanie dążeń, które rozpoznaje w swej woli życia. „Poznanie świata może mu mówić, że problematyczne jest jego dążenie, by doprowadzić do najwyższej wartości życie swoje i każde inne, na które ma wpływ. Nie daje się on przez to zwieść. Jego afirmacja świata $\mathrm{i}$ życia ma sens $w$ sobie samej. Wynika ona $z$ wewnętrznej konieczności i wystarcza sobie. Dzięki niej moja egzystencja realizuje cele tajemniczej, powszechnej woli życia, której jestem przejawem"51.

Analizując wyższą afirmację życia Schweitzer stwierdza, że człowiek musi stać się inny niż świat, aby mógł trwać i działać w prawdziwej harmonii $z$ duchem świata ${ }^{52}$. Niemożność odkrycia dlaczego człowiek musi

47 Por. A. SCHWEITZER, Kultur und Ethik in den Weltreligionen, Werke aus dem Nachlaß, München 2001, 170.

48 Por. A. SCHWEITZER, Das Problem, dz. cyt., 157.

49 Por. C. GÜNZLER, Einleitung (Wprowadzenie), w: A. SCHWEITZER, Die Weltanschauung der Ehrfurcht, dz. cyt., t. 1/2, 21.

5) Por. A. SCHWEITZER, Kultur und Ethik, dz.cyt., 349.

51 Por, tamże, 345-347.

52 Por. tamże, 313

W notatkach do III tomu Filozofii kultury znajdujemy proste stwierdzenie, że życie w harmonii ze światem nie jest życiem w harmonii z zasadą tego, co się wydarza. „Vivre en harmonie avec le monde (ne veut) pas dire vivre en harmonie avec le proncipe des événements". Por. A. SCHWEITZER, Die Weltanschauung der Ehrfurcht, dz. cyt., t. 1/2, 458. 
żyć inaczej niż żyje świat, oraz świadomość, że działania zmierzające do znoszenia rozdwojenia woli życia mają znikomy skutek dla świata sprawiają, że człowiek żyje w świecie jako obcy. Obcość ta obciążona jest ponadto świadomością zniewolenia, ponieważ zmuszeni jesteśmy do praktycznego podporządkowania się prawom niszczenia innych, których to praw nie akceptujemy ${ }^{53}$.

\section{Ocena propozycji Schweitzer}

Chaotyczność i bezcelowość świata dostrzegana przez Schweitzera skłaniają go do maksymalnego zdystansowania się do przekonania, że możliwa jest harmonia między człowiekiem i natura. Mimo to poszukuje on ujęcia, które uzasadniałoby owo harmonijne wspótistnienie oparte na afirmacji świata i życia. Sformułowaniu takiego rozumienia świata służy postulat, aby wyprowadzać pogląd na świat z poglądu na życie, a nie odwrotnie. Takie rozumowanie umożliwiałoby afirmację świata bez konieczności zrozumienia i zaakceptowania praw nim rządzących. Określony przez Schweitzera dualizm człowiek - natura okazuje się jednak być nie do pokonania. Etyka budowana na radykalnej i pierwotnej afirmacji życia, w oderwaniu, czy wręcz w opozycji do poznania świata nie daje się pogodzić z tym, jaki jest świat ${ }^{54}$.

Wewnętrzne doświadczenie siebie jako woli życia jest dla Schweitzera pewniejszym źródłem wiedzy o świecie niż empiryczne poznanie tego świata $^{55}$. Stąd wiedza ujmowana jest przez Schweitzera wręcz woluntarystycznie - jako poznawanie woli życia, doświadczanie jej. Takie rozumienie znajdujemy w podsumowaniu wywodu o wyższości poznania płynącego z woli życia: "Najwyższą więc wiedzą jest wiedzieć, że muszę być wiernym woli życia. To daje mi kompas (...) itd."56. A zatem, postulat rezygnacji poznawczej rozumianej jako konieczny krok zbudowania prawdziwego światopoglądu nie jest spełniony przez samego Schweitzera ${ }^{57}$,

53 Por. A. SCHWEITZER, Die Weltanschauung der Ehrfurcht, dz. cyt., t. 3/4, 45.

54 Por. C. GÜNZLER, Einleitung, dz. cyt., 21n. Günzler stwierdza, że w 1945 r. Schweitzer zrezygnowal ostatecznie z prób przekroczenia owego dualizmu.

55 Por. A. P. BARSAM, Schweitzer, Jainism and Reverence for Life, w: Reverence for Life. The Ethics of Albert Schweitzer for the Twenty-First Century, red. M. Meyer i K. Bergel, Syracuse 2002, 218n.

Sh. Por. A. SCHWEITZER, Kultur ind Ethik, dz. cyt., 345n.

57 Schweitzer byl oczywiście przekonany, że realizuje swój postulat. W 1951 r. stwierdza na przykład, że 25 lat wcześniej, gdy ogłaszal niepoznawalność świata i niemożliwość zbudowania filozofii w oparciu o jego poznanie, ówczesna filozofia fachowa ,nie brala pod uwagę", że kiedyś będzie musiała przyjąć ten pogląd. Obecnie zaś jest ona zmuszona to uczynić pod wplywem wiedzy dostarczanej przez nauki szczególowe. Por. E. GRÄSSER, Studien zu Albert Schweitzer. Gesammelte Aufsätze, Bodenheim 1997, 107. 
który posiada własną interpretację świata, przypisującą poznaniu świata niewielkie znaczenie. Interpretacja ta oraz teza o niepoznawalności świata pozwalają zrezygnować z poznawania go i zwrócić się ku woli życia, aby w niej znaleźć źródło afirmacji życia i świata. Doświadczenie własnej woli życia zostaje uznane za najbardziej bezpośrednie i oczywiste. Podejście takie można określić mianem intuicjonizmu, w którym doświadczenie wewnętrzne staje się źródłem i kryterium poznawania prawdy.

Agnostyczne podejście do poznania świata sprawia, że Schweitzer postuluje odnalezienie reguł moralności wewnątrz świadomości człowieka, gdzie dokonuje się poznanie właściwego stosunku do świata. Tym podstawowym odniesieniem jest - jego zdaniem - cześć dla życia płynąca z głębokiej jego afirmacji ${ }^{58}$. Za jedyną miarę wartości zostaje uznane poszukiwanie tego, co ostateczne i najbardziej podstawowe. „Tylko w tej mierze, w jakiej cele, które stawia sobie działanie, dają się wyprowadzić z sensu mojego życia i życia innych, moje chcenie i działanie jest sensowne i wartościowe" ${ }^{\prime 59}$. Koncentracja jedynie na tym, co najbardziej podstawowe, sprawia, że Schweitzer pomija inne wartości i jest przekonany, że $z$ owej najbardziej elementarnej prawdy można będzie bezpośrednio wywieść normy wszelkich odniesień moralnych. Uważa się on za tego, który pierwszy czyni to, czego nie udało się dokonać wcześniejszym myślicielom - wskazuje podstawową normę moralną: cześć dla życia, z której ma wynikać troska o trwanie i rozwój życia. Norma ta ma wystarczyć człowiekowi do samodzielnego podejmowania decyzji ${ }^{60}$.

W ten sposób Schweitzer ucieka od etyki wartości, poprzestając na określeniu normy zasadniczej i nie określając sposobów jej realizacji. Możliwe ujęcia etyki ukazuje on w wąskiej alternatywie: etyka wartości lub etyka $\mathrm{czci}^{61}$. Rezygnacja $\mathrm{z}$ odniesienia do wartości prowadzi Schweitzera do nieuzasadnionych uproszczeń. Na przykład wartościowanie zabijania przez niego dokonane opiera się na bardzo uproszczonej dychotomii. Ukazuje on jedynie dwie możliwości: zabijanie konieczne lub bezmyślne, stwierdzając, że to drugie jest całkowicie niedopuszczalne ${ }^{62}$. Istnieje jednak wiele sytuacji, kiedy ktoś występuje przeciw życiu nie z konieczności, ale jednak w sposób zamierzony, nie bezmyślny. Zerwanie kwiatów, by komuś je ofiarować, czy zabijanie owadów, które choć nie zagrażają życiu człowieka, mogą być bardzo uciążliwe - to przykłady sy-

\footnotetext{
58 Por. A. SCHWEITZER, Das Problem, dz. cyt., 157n.

59 A. SCHWEITZER, Verfall, dz.cyt., 89.

60 Por. tamże, 90.

61 Por. E. GRÄSSER, Studien, dz. cyt., 76.

62 „Wieśniak, który skosił na łące tysiące kwiatów na paszę dla swych krów, nie ma prawa w powrotnej drodze zerwać bezmyślnie ani jednego kwiatu, ponieważ w ten sposób wykracza przeciwko życiu, nie będąc do tego zmuszony". A. SCHWEITZER, Życie, dz. cyt., 60.
} 
tuacji wymykających się wspomnianej dychotomii Schweitzera. Niszczenie życia nie jest $w$ takich przypadkach konieczne, trudno jednak stwierdzić, że jest ono nieuzasadnione. Aby ocenić dopuszczalność takiego wystąpienia przeciwko życiu, potrzeba odniesienia się do wartości, czego Schweitzer zupełnie nie czyni. To staje się najpoważniejszym zarzutem przeciwko jego etyce ${ }^{63}$.

Uświadomiwszy sobie istnienie woli życia, Schweitzer uznaje ją za ostateczny punkt odniesienia dla etyki. Fakt, że wszystko jest przejawem tej woli, jawi mu się jako tak oczywisty, że nie próbuje nawet w żaden sposób go uzasadniać. Doświadczenie woli życia ma charakter jakiejś pierwotnej intuicji, która rozpoznaje tę wolę we wszystkim w niekwestionowany sposób. Opisana powyżej droga wkraczania na wyżyny poznania, gdzie należy oddać się doświadczanej w sobie woli życia, przypomina ujęcia intuicjonistyczne, jeśli nie opisy przeżyć towarzyszących ezoterycznej inicjacji: „[Poznanie] napełnia mnie czcią dla tajemniczej woli życia, która istnieje we wszystkim. Czyniąc mnie myślącym i zadziwionym, prowadzi mnie wzwyż - na wyżyny czci dla życia. Tu puszcza moją rękę. Dalej nie może mnie prowadzić. Teraz moja wola życia musi sama szukać swej drogi w świecie"64.

Schweitzer nie podaje uzasadnienia, dlaczego doświadczenie swej woli życia ma tak podstawowe znaczenie, a przecież nie jest to wcale oczywiste. Człowiek, jako istota świadoma siebie, myśląca i chcąca, pozostająca $\mathrm{w}$ różnorodnych relacjach, może odpowiedzieć w bardzo różny sposób na fundamentalne pytanie: 'kim jestem?', zwłaszcza, że już samo sformułowanie owego fundamentalnego pytania nie jest oczywiste. Schweitzer bowiem odpowiada raczej na pytanie: 'czym jestem?'.

Racjonalizm doprowadzony do końca - zdaniem Schweitzera - przechodzi w irracjonalizm, co ma stanowić konieczny paradoks życia duchowego. Przyczyną koniecznego pojawienia się w rozumowaniu Schweitzera irracjonalności wydaje się być jednak względność jego racjonalizmu. Myślenie rozumowe nie jest dla niego - wbrew deklaracjom - ostatecznym źródłem poznania ${ }^{65}$. Jest ono jedynie narzędziem, które ma służyć do analizy treści odnajdywanych $w$ woli, albowiem wiedza płynąca $z$ doświadczenia woli wydaje się Schweitzerowi najpewniejsza. Negując możliwość poznania świata i dokonując aktu rezygnacji poznawczej, człowiek skazuje się na irracjonalne tłumaczenie świata. Irracjonalizm nie jest więc końcowym rezultatem przemyśleń Schweitzera, lecz pojawia się u samego ich początku.

\footnotetext{
6.3 Por. H. GROOS, Albert Schweitzer. Größe und Grenzen. Eine kritische Würdigung des Forschers und Denkers, München-Basel 1974, 521n.

64 A. SCHWEITZER, Kultur und Ethik, dz. cyt., 377. Tekst polski według: I. LAZARI-PAWLOWSKA. Schweitzer, dz. cyt., 183.

65 Por. A. SCHWEITZER, Verfall, dz. cyt., 82.
} 
Postulowana przez Schweitzera autonomia wobec praw świata polega ostatecznie na pominięciu prawdy o tym jaki jest świat. Pozostaje ona atrakcyjną utopią bycia dobrym wśród świata, który pełen jest niszczycielskich sił. Schweitzerowi nie przeszkadza fakt, że jego postulaty są niemożliwe do zrealizowania.

\section{Bibliografia}

Dzieła Alberta Schweitzera

Das Problem der Ethik in der Höherentwicklung des menschlichen Denkens, w: Ausgewählte Werke in fünf Bänden, Berlin 1973, t. V, 143-159.

Die Weltanschauung der Ehrfurcht vor dem Leben. Kulturphilosphie III - Erster und zweiter Teil, Werke aus dem Nachlaß, München 1999.

Die Weltanschauung der Ehrfurcht vor dem Leben. Kulturphilosphie III - Dritter und vierter Teil, Werke aus dem Nachlaß, München 2000.

Kultur und Ethik in den Weltreligionen, Werke aus dem Nachlaß, München 2001.

Kultur und Ethik, w: Ausgewählte Werke in fünf Bänden, Berlin 1973, t. II, 95-420.

Strassburger Vorlesungen, Werke aus dem Nachlaß, München 1998.

The Ethics of Reverence for Life, w: Christendom I, Winter 1936, no. 2, przedruk w: Clark Henry, The Philosophy of Albert Schweitzer, London 1964, 180-194.

Verfall und Wiederaufbau der Kultur, w: Ausgew'ählte Werke in fünf Bänden, Berlin 1973, t. II, 17-94.

Wielcy myśliciele Indii, tłum. z j. franc. K. i K. Pruscy, Warszawa 1993.

Życie, thum. z j. niem. J. Piechowski, Warszawa 1971.

\section{Inne}

BABEL H., 1962 - Die Ethik der Ehrfurcht vor dem Leben - eine Darstellung, w: Albert Schw'eitzer. Sein Denken und sein Weg, red. H. W. Bähr, Tübingen, 24-30.

BARSAM A. P., 2002 - Schweitzer, Jainism and Reverence for Life, w: Reverence for Life. The Ethics of Albert Schweitzer for the Twenty-First Century, red. Marvin Meyer, Kurt Bergel, Syracuse, 207-245.

CLARK H., 1964 - The Philosophy of Albert Schweitzer, London.

ECKER M., Evolution und Ethik. Der Begriff der Denknotw'endigkeit in Albert Schweitzers Ethik der Ehrfurcht vor dem Leben, w: Albert Schweitzer heute. Brennpunkte seines Denkens, red. C. Giinzler, E. Grässer, B. Christ, H. H. Eggebrecht, Tübingen 1990, 51-81.

GRÄSSER E., 1997 - Studien zu Albert Schweitzer. Gesammelte Aufsätze, Bodenheim.

GROOS H., 1974 - Albert Schweitzer. Größe und Grenzen. Eine kritische Würdigung des Forschers und Denkers, München - Basel.

GÜNZLER C., 1999 - Einleitung, w: A. SCHWEITZER, Die Weltanschauung der Ehrfurcht vor dem Leben. Kulturphilosphie III, Werke aus dem Nachlaß, München, 18-28.

HYGEN J. B., 1962 - Niedergang und Wiederaufbau der Kultur-Die Kulturphilosophie Albert Schweitzers, w: Albert Schweitzer. Sein Denken und sein Weg, red. H. W. Bähr, Tübingen, 318.

LAZARI-PAWŁOWSKA I., 1976 - Schweitzer, Warszawa. 


\section{Autonomy against the laws ruling the world as a condition of being really moral in the philosophy of Albert Schweitzer}

\section{SUMMARY}

The ethics of Albert Schweitzer is subjectivistic. He postulates the autonomy against the laws ruling the world and defines the general moral principle basing it on the inner experience ofwill-to-live. This comes from his conviction that we are not able to discover the meaning of the world's existence. He suggests an act of cognitive resignation - stopping to search for the meaning ofthe world and turning towards one's inside.

Schweitzer finds the laws ruling the world to be cruel, allowing killing other creatures. A maral human being will never accept such rules. Striving to be faithful to the inner truth of his will-to-live, he will totally affirm the life opposing everything what happens around him.

Schweitzer's postulate ignores the truth about the world. It is an attractive utopia of being good within a world which is full of destruction. Schweitzer, however, do es not care that his postulates are impossible to be fulfilled. 